\title{
OAK RIDGE INSTITUTE OF NUCLEAR STUDIES RADIOCARBON DATES I
}

\author{
JOHN E. NOAKES, S. M. KIM and L. K. AKERS
}

Special Training Division, Oak Ridge Institute of Nuclear Studies Oak Ridge, Tennessee

The Radiocarbon Dating Laboratory of the Oak Ridge Institute of Nuclear Studies (ORINS) was developed as a teaching and research facility in the Special Training Division. This facility is available to participants enrolled in various courses held at ORINS, research groups associated with the 41 universities that make up the Oak Ridge Associated Universities (ORAU), and other colleges, unversities or institutions interested in this lab for teaching or research.

Carbon samples are synthesized to liquid benzene; $\mathrm{C}^{14}$ activity is determined by liquid-scintillation spectroscopy. Samples are first converted to lithium carbide and then to acetylene gas as described by Barker (1953). The acetylene is trimerized to benzene through the use of a vanadium alumina catalyst developed at ORINS. Chemical yields for the benzene synthesized routinely approaches $90 \%$ with no evidence of chemical impurities in the benzene to cause quenching nor of carbonisotope fractionation occurring in the chemistry. Benzene chemistry, catalyst, benzene purity, and $\mathrm{C}^{13} / \mathrm{C}^{12}$ isotope-fractionation studies are reported by Noakes et al. (1965).

The liquid scintillation spectrometer used is a modified Packard Tricarb Model 314 D C. Counting efficiency is $50 \%$ when operating at a voltage of 800 with discriminator settings of 100-800-1000. Background count rate is $1.7 \mathrm{c} / \mathrm{m}$ with a $5 \mathrm{cc}$ benzene sample. Shielding consists of $4 \mathrm{in}$. of lead with coincidence and anticoincidence systems.

The modern reference standard used is $0.95 \%$ of the activity of the NBS oxalic-acid standard which is $6.82 \mathrm{c} / \mathrm{m} / \mathrm{g}$ carbon. Ages are calculated on a $\mathrm{C}^{14}$ half-life of 5570 as suggested by Godwin (1962). The statistics quoted are compiled as one standard deviation $(1 \sigma)$ of the uncertainty involved in counting background, standard and sample.

\section{ACKNOWLEDGMENTS}

Dr. Rainer Berger, Radioisotopes Laboratory, University of California at Los Angeles contributed interlaboratory check samples. Dr. Brian Logan, Geology Department, University of Western Australia contributed many samples and helped in the evaluation. Mr. Fred Fisher, an ORAU Student Trainee from Colorado College, helped in sample preparation and counting.

Financial support was received from the Division of Biology and Medicine and the Division of Nuclear Education and Training through the ORAU contract with the Atomic Energy Commission, No. AT (40-1)GEN-33. 
SAMPLE DESGRIPTIONS

$\quad$ Sample
ORINS-1
UCLA-908
ORINS-2
UCLA-568A
ORINS-47
UCLA-752
ORINS-51
UCLA-787A

I. CHECK SAMPLES

\begin{tabular}{|c|c|}
\hline Age & Reference \\
\hline $1070 \pm 190$ & ORINS-1 \\
\hline $920 \pm 80$ & UCLA-IV \\
\hline $980 \pm 160$ & ORINS-I \\
\hline $\mathbf{8 1 5} \pm \mathbf{8 0}$ & UCLA-IV \\
\hline $3340 \pm 160$ & ORINS-I \\
\hline $3255 \pm 80$ & UCLA-IV \\
\hline $14980 \pm 180$ & ORINS-I \\
\hline $15540 \pm \mathbf{2 8 0}$ & UCLA-IV \\
\hline
\end{tabular}

II. GEOLOGIC SAMPLES

\section{A. Shark Bay, Western Australia}

Shark Bay is a lagoonal sea lying between $24^{\circ} 30^{\prime} \mathrm{S}$ and $26^{\circ} 45^{\prime} \mathrm{S}$ lat on west coast of Australia. Since 1964 a marine-research group from Dept. of Geology, Univ. of Western Australia has been conducting research program on carbonate sedimentation and diagenesis of carbonate sediments in Shark Bay. The following $\mathrm{C}^{14}$ dates are mainly on shell materials obtained from emergent Quaternary sediments in the area.

ORINS-19. Shark Bay, Sample L165044

$>27,000$

Coral fragment (Favia sp) from intertidal-supratidal bench, $\mathrm{E}$ shore Hamelin Pool, W. A. Zone 1, Natl. Co-ordinate Grid 1725450 N, 205120 E. Obtained from cobble-size fragment cemented into matrix of indurated calcarenite surfacing the bench. Calcarenite occurs as thin (2-6 in) veneer overlying Cretaceous orthoquartzites and dolomites. Surface of bench ca. 6 in. above normal HWS level. Coll. April 1965; subm. by Brian W. Logan, Dept. of Geology, University of W Australia. Com ment: corals do not live in hypersaline water of Hamelin Pool at present; only known living occurrences of this species of coral in Shark Bay are $\mathrm{N}$ of Lat $25^{\circ} 40^{\prime} \mathrm{S}$ where salinities are 30 to $42 \%$. Date and occurrence suggest that pre-glacial Shark Bay had lower salinities than those of present day. Petrographic examination indicated no significant diagenetic alteration in the skeleton.

\section{ORINS-33. Shark Bay, Sample L165047}

$1880 \pm 180$

70 A.D.

Oöids from eolian dune, ca. $300 \mathrm{ft}$ landward of shoreline; same locality as ORINS-19 (L165044). Coll. April 1965; subm. by Brian W. Logan. Comment: sample dated to determine whether oöid dunes are forming in present depositional cycle.

ORINS-3. Shark Bay, Sample L165069

Valves of pelecypod (Cryptogramma squammosa) from excavation ca. $4 \mathrm{ft}$ below surface of claypan in matrix of fine quartz sand at southern end of Hamelin Pool, W Australia. W. A. Zone 1, Natl. Co-ordinate 
Grid 1703400 N, 189050 E. Most valves were disarticulate. Shell bed is same stratigraphic horizon from which ORINS-27 (L165066) obtained; this horizon is at $+15 \mathrm{ft}$ HWS in Hamelin Pool. Coll. April 1965; subm. by Brian W. Logan.

\section{ORINS-27. Shark Bay, Sample L165066}

$24,530 \pm 750$

Valves of pelecypod (Cryptogramma squammosa) from shallow borehole in gypsum pan at southern end of Hamelin Pool. W. A. Zone 1, Natl. Co-ordinate Grid 1701150 N, 190600 E. Borehole penetrated ca. $5 \mathrm{ft}$ of sandy gypsum and bottomed on shell layer with abundant Cryptogramma and cerithiid gastropods. Locality lies landward of series of coquina ridges and intertidal-supratidal flats. Elev. of horizon with Cyrptogramma is $+15 \mathrm{ft}$ above HWS in Hamelin Pool. Coll. April 1965; subm. by Brian W. Logan. Comment: date should be compared with ORINS-3 (L165069) from same horizon; indicates that sample probably contains younger diagenetic carbon.

\section{ORINS-30. Shark Bay, Sample L165084-1 \\ $31,390 \pm 400$ \\ 29,440 в.c.}

Valves of pelecypod Tellina virgata from emergent shell bed occurring in low bluffs bordering a tidal channel into "Small Lagoon", $1 \mathrm{mi}$ $\mathrm{N}$ of Denham, W. A. Zone 1, Natl. Co-ordinate Grid 1778800 N, 129000 E. Horizon is overlain by ca. $3 \mathrm{ft}$ of dune sand; maximum elev. is approx. $+4 \mathrm{ft}$ above HWS. Subm. by Brian W. Logan. Comment: comparison with ORINS-5 in same horizon indicates contamination by younger diagenetic carbon.

ORINS-5. Shark Bay, Sample L165-84-2

Valves of pelecypod Circe sugillata from same locality and horizon as ORINS-30 (L165084-1). Coll. April 1965; subm. Brian W. Logan. Comment: comparison with ORINS-30 suggests contamination by younger diagenetic carbon in these samples.

\section{ORINS-16. Shark Bay, Sample L165098}

$4860 \pm 235$

Valves of pelecypod Fragum unedo from below surface of supratidal end of Lharidon Bight, Shark Bay, Zone 1, Natl. Co-ordinate Grid 1743500 N, 149500 E. From highly fossiliferous horizon ca. l ft below surface and beneath $1-\mathrm{ft}$ crust of gypseous carbonate; shell horizon overlies weathered surface on top of older fossiliferous horizon containing ORINS-28 (L165092). Cia. 1 to $2 \mathrm{ft}$ above present sealevel. Material is part of marine sequence in abandoned marine channel. Coll. April 1965; subm. by Brian W. Logan.

\section{ORINS-28. Shark Bay, Sample L165092}

$24,070 \pm 450$

Valves of assorted pelecypods Chama sp, Hemicardium tumoriforim, Circe sugillata, Placamen placidum, from emergent shell bed, approx. 1 mi $\mathrm{N}$ of airfield, Lharidon Bight, Shark Bay, W Australia. W. A. Zone 1, 
Natl. Co-ordinate Grid $1744100 \mathrm{~N}, 150500 \mathrm{E}$. Bed extends from $+6 \mathrm{ft}$ above HWS to below sealevel and underlies horizon from which ORINS16 (L165098) was obtained. Coll. April 1965; subm. by Brian W. Logan.

\section{ORINS-22. Shark Bay, Sample L165079-1}

Valves of pelecypod Cryptogramma squammosa from emergent shell bed, at "Gregory", Shark Bay. W. A. Zone 1, Natl. Co-ordinate Grid 1820900 N, 122700 E between Peron Sandstone and dune sand. Horizon is 2 to $3 \mathrm{ft}$ thick; elev approx. $6 \mathrm{ft}$ above HWS (see Logan, 1959). Coll. April 1965; subm. by Brian W. Logan.

ORINS-23. Shark Bay, Sample L165079-2

Valves of pelecypod species (Hemicardium tumoriforum) from same locality as ORINS-22 (L165079-1).

\section{ORINS-24. Shark Bay, Sample L165079-3}

Valves of pelecypod Circe sugillata and C. plicatina, from same locality and stratigraphic horizon as ORINS-22 (L165079-1) and ORINS-23 (L165079-2).

\section{ORINS-29. Shark Bay, Sample L165082}

$26,920 \pm 830$

of Cape Peron pelecypod Chama sp from margins of large gypsum pan $\mathrm{S}$ of Cape Peron North, Shark Bay. W. A. Zone 1, Natl. Co-ordinate Grid $1820900 \mathrm{~N}, 122700 \mathrm{E}$. Shells were broken out of quartzose limestone probably equivalent stratigraphically to horizon that yielded ORINS-22 (L165079-1), ORINS-23 (L165079-2) and ORINS-24 (L165079-3). Comment: comparison with other dates from this horizon suggests all shells have some addition of younger, diagenetic carbon.

\section{ORINS-31. Shark Bay, Sample L165079-4 \\ $24,000 \pm 280$}

horizalves of pelecypod Pinctada carchariarium from same locality and horizon as ORINS-22 (L165079-1), ORINS-23 (L165079-2) and ORINS24 (L165079-3). Comment: age is probably affected by introduction of younger diagenetic carbon.

\section{ORINS-41. Shark Bay, Sample GD4 \\ $5040 \pm 165$ \\ 3090 B.c.}

Marine bivalve Fragum unedo Linn from unconsolidated shell bed beneath gypseous dune, Gladstone supratidal flat, Shark Bay. W. A. Zone 1, Natl. Co-ordinate Grid $1769400 \mathrm{~N}, 211300$ E. Bed approx. $2 \mathrm{mi}$ from present mean high-tide strandline and ca. $5 \mathrm{ft}$ above mean sealevel. Coll. July 1965; subm. by G.R. Davies, Dept. of Geology, Univ. of W Australia, Nedlands. Comment: varied mollusk fauna of shell bed represents sandflat facies of lower-salinity environment than in present embayment, in which salinities range from 50 to $64 \%$. This date, with ORINS-39 (GD5), suggests higher sealevel in sub-Recent with more open circulation and lower salinities. 
ORINS-39. Shark Bay, Sample GD5

$3910 \pm 200$ of cliffine bivalve Fragum unedo Linn from shell bed in gully at base of cliff cut in older Pleistocene marine oolite, $5 \mathrm{mi} \mathrm{N}$ of Gladstone jetty, Shark Bay. W. A. Zone 1, Natl. Co-ordinate Grid 1782300 N, 210100 E. Bed approx. 100 yd from mean high-tide strandline and ca. $5 \mathrm{ft}$ above mean sealevel. Coll. July 1965; subm. by G. R. Davies.

\section{ORINS-42. Shark Bay, Sample GD9}

$39,100 \pm 600$

37,150 B.c.

fringine of Spondylus sp from mollusk fauna associated with coral fringing reef (fossil) on bench cut in Toolonga Calcilutite (Cretaceous), S Gladstone supratidal flat, Shark Bay, W. A. Zone 1, Natl. Co-ordinate Grid $1769900 \mathrm{~N}, 206200 \mathrm{E}$. From surface of flat ca. 3 to $5 \mathrm{ft}$ above mean sealevel, 300 yd from mean high-tide strandline. Coll. July 1965; subm. by G. R. Davies. Comment: sample cut from center of massive valve. No evidence of alteration or contamination. Extensive development of fossil fringing reef with associated heavy-shelled mollusk fauna occurs below supratidal sediments in the area. This suggests higher sealevel, lower salinities than in present embayment.

\section{ORINS-34. Shark Bay, Sample GD11}

$>33,400$

Coral Cyphastrea sp from shell bed $18 \mathrm{ft}$ above mean sealevel, $5 \mathrm{mi}$ $\mathrm{N}$ of Gladstone jetty, Shark Bay. W. A. Zone 1, Natl. Co-ordinate Grid $1782300 \mathrm{~N}, 210100 \mathrm{E}$. Bed 12 to 18 in. thick is exposed at top of cliff cut in Pleistocene marine oolite. Overlain by kunkar and soil horizon 12 in. thick. Coll. July 1965; subm. by G. R. Davies. Comment: sample cut from center of head of coral 8 in. diam. Coral head not considered in situ. Rich and varied mollusk fauna of shell bed is characterized by abundance of still-articulated bivalves. Fauna represents sand-flat facies of lower salinity than in present Gladstone embayment.

\section{ORINS-40. Shark Bay, Sample GD12 \\ $28,850 \pm 400$}

Coral Porites sp from fossil fringing reef, S Gladstone supratidal flat, Shark Bay. W. A. Zone I, Natl. Co-ordinate Grid 1769900 N, 206200 E. Coral on bench cut in Toolonga Calcilutite (Cretaceous) ca. 3 to $5 \mathrm{ft}$ above mean sealevel, 300 yd from mean high-tide strandline. Coll. July 1965, subm.by G. R. Davies. Comment: cut from center of small head of Porites. Date does not correspond with ORINS-42 (GD9), from same locality, although supporting Pleistocene age. Some contamination by younger carbonate possible in porous corallum, with additional possibility of partial recrystallisation of aragonite.

\section{ORINS-32. Shark Bay, Sample L265604}

$32,640 \pm 300$

Valves of pelecypod Anadara sp from Pleistocene Guildford Clay Formation, Obtained in clay pits, Guildford, W Australia. Bed is de- 
scribed in Fairbridge (1954) and Anadara horizon is believed to be 15 to $20 \mathrm{ft}$ above sealevel. Coll. 1965; subm. by Brian W. Logan, Comment: shells are much altered and contamination by young, diagenetic carbon is probable.

ORINS-20. Shark Bay, Sample L1651553

$>34,000$

Sample of coral Pocillopora sp from Pleistocene reef at Point Leander, Dongara, $10 \mathrm{ft}$ above present MSL. Coral was in growth position; thin-section examination suggests little diagenetic alteration. Small amounts of void-filling calcite (ca. $5 \%$ of total bulk) were present. Coll. July 1964; subm. by Brian W. Logan.

\section{ORINS-21. Shark Bay, Sample L1651554 \\ $15,980 \pm 230$}

Lithothamnium sp from Pleistocene reef at same locality as ORINS20 (L1651553). Comment: comparison with ORINS-20 indicates significant addition of younger diagenetic carbon in ORINS-21.

\section{B. Campeche Bank, Yucatan}

Series of long cores were taken from Campeche Bank, Yucatan for study of physical, chemical, and geochemical properties of carbonate sediments in area. Cores were collected on various cruises of Texas A \& M research vessel R.V. Alaminos during 1965 and 1966.

Calcareous lutite from upper and lower sections (intervals 110 to $120 \mathrm{~cm}, 310$ to $320 \mathrm{~cm}$ and 1135 to $1150 \mathrm{~cm}$ ) of core from Campeche Bank (20 $59^{\prime} \mathrm{N}$ Lat, $96^{\circ} 26^{\prime} \mathrm{W}$ Long), depth $228 \mathrm{~m}$. Coll. March 24, 1965 by William Bryant, Dep. of Geol.Oceanography, Texas A \& M Univ., Texas; subm. June 1965. Comment: Shell Research and Development Corporation at Houston, Texas $\mathrm{C}^{14}$ dates tabulated to show chronology of core.

\begin{tabular}{|c|c|c|}
\hline Lab. No. & Core Interval $(\mathrm{cm})$ & $\mathrm{C}^{14}$ Date \\
\hline ORINS-37 & 110-120 & $\begin{array}{l}16,340 \pm 265 \\
14,390 \text { в.с. }\end{array}$ \\
\hline ORINS-36 & 310-320 & $\begin{array}{l}17,590 \pm 340 \\
15,640 \text { в.с. }\end{array}$ \\
\hline Sh-100 & $610-620$ & $\begin{array}{l}19,000 \pm 800 \\
17,050 \text { в.с. }\end{array}$ \\
\hline Sh-101 & $780-790$ & $\begin{array}{l}25,200 \pm 1500 \\
23,240 \text { в.с. }\end{array}$ \\
\hline Sh-102 & $1060-1070$ & $\begin{array}{l}33,600 \pm 4100 \\
31,650 \text { в.с. }\end{array}$ \\
\hline ORINS-48 & $\mathbf{1 1 3 5 - 1 1 5 0}$ & $\begin{array}{l}40,700 \pm 1700 \\
38,750 \text { в.C. }\end{array}$ \\
\hline
\end{tabular}




\title{
C. Sapelo Island, Georgia
}

ORINS-25. Sapelo Island, Georgia Sample 17-26

Sapelo Island shell material (Crossostrea virginica) from core of low dune formation ( $31^{\circ} 27^{\prime} 10^{\prime \prime} \mathrm{N}$ Lat, $81^{\circ} 15^{\prime} 33^{\prime \prime} \mathrm{W}$ Long) $16 \mathrm{ft}$ below MLW. Coll. and subm. by J. H. Hoyt, Univ. of Georgia, Marine Inst., Sapelo Island. Comment: shells, worn and smooth, suggesting reworking, orcur in clayey sand of Silver Bluff formation.

Dite list:

\section{REFERENCES}

\author{
UCLA IV Berger, Fergusson, Libby, 1965
}

Barker, H., 1953, Radiocarbon dating; large scale preparation of acetylene from organic material: Nature, v. 172, p. 631-632.

Fairbridge, R. W., 1954, Quaternary eustatic data from Western Australia and adjacent states: Proc. Pan Indian Ocean Sci. Cong., Perth, August 1954, Sec. F, p. 64-84.

Gordwin, H., 1962, Half-life of radiocarbon: Nature, v. 195, p. 984.

Logan, B. W., 1959, Environments, foraminiferal facies and sediments of Shark Bay, Western Australia: Ph.D. dissertation, Dept. of Geology, Univ. of W. Australia, $287 \mathrm{p}$.

Noakes, J. E., Kim, S. M., Stipp, J. J. and Akers, L. K., 1965, Chemical and counting advances in liquid scintillation radiocarbon dating: Sixth Internat. Conf. Radiocarbon and Tritium Dating, Proc., Conf. -650652, p. 68-92. 